\title{
Source rock geochemistry of shale samples from Ege-1 and Ege-2 wells, Niger Delta, Nigeria
}

\author{
S. L. Fadiya ${ }^{1}\left[\right.$ - S. A. Adekola' ${ }^{1}$ B. M. Oyebamiji ${ }^{2}$ O. T. Akinsanpe ${ }^{1}$
}

Received: 19 August 2020 / Accepted: 2 November 2020 / Published online: 12 November 2020

(c) The Author(s) 2020

\begin{abstract}
Selected shale samples within the middle Miocene Agbada Formation of Ege-1 and Ege-2 wells, Niger Delta Basin, Nigeria, were evaluated using total organic carbon content (TOC) and Rock-Eval pyrolysis examination with the aim of determining their hydrocarbon potential. The results obtained reveal TOC values varying from 1.64 to $2.77 \mathrm{wt} \%$ with an average value of $2.29 \mathrm{wt} \%$ for Ege-1 well, while Ege-2 well TOC values ranged from 1.27 to $3.28 \mathrm{wt} \%$ (average of $2.27 \mathrm{wt} \%$ ) values which both fall above the minimum threshold $(0.5 \%)$ for hydrocarbon generation potential in the Niger Delta. Rock-Eval pyrolysis data revealed that the shale source rock samples from Ege-1 well are characterized by Type II-Type III kerogens which are thermally mature to generate oil or gas/oil. The Ege-2 well pyrolysis result showed that some of the ditch cutting samples are comprised of Type II (oil prone) and Type III (gas-prone kerogen) which are thermally immature to marginal maturity $\left(T_{\max } 346-439^{\circ} \mathrm{C}\right)$. This study concludes that the shale intercalations between reservoir sands of the Agbada Formation are good source rocks in early maturity and also must have contributed to the vast petroleum reserve in the Niger Delta Basin because of the subsidence of the basin.
\end{abstract}

Keywords Agbada Formation $\cdot$ Niger Delta $\cdot$ Hydrocarbon potential $\cdot$ Total organic carbon $\cdot$ Rock-Eval

\section{Introduction}

The geochemistry of sedimentary rocks is vital to deduce factors that control sediment characteristics during and after their deposition and also to describe the relationship between specific units of both clastic and carbonate strata (Nagarajan et al. 2007; Madhavaraju and Lee 2009). The significance of geochemistry in describing the origin of sedimentary rocks, paleo-weathering conditions as well as tectonic evolutions of sedimentary basins is recognized in many studies (Cullers et al. 1988; Nagarajan et al. 2007; Frimmel 2009). Organic geochemical analyses are unique in determining the hydrocarbon potential of sedimentary rocks as well as playing a pivotal role in the continued development of oil and gas exploration and production (Philp 2014). These analyses

S. L. Fadiya

slfadiya@oauife.edu.ng; fadiyalawrence@yahoo.co.uk

1 Department of Geology, Obafemi Awolowo University, Ile-Ife, Nigeria

2 Department of Geology, University of Lagos, Lagos, Nigeria have been a significant tool in determining the hydrocarbon prospectivity of the Niger Delta.

The Niger Delta is located on the western coast of Africa between Latitudes $3^{\circ} 50^{\prime}$ and $6^{\circ} 50^{\prime}$ North and Longitudes $3^{\circ} 25^{\prime}$ and $8^{\circ} 50^{\prime}$ (Fig. 1; Akinsanpe and Benjamin 2018). The delta is one of the world's largest complexes and a prolific hydrocarbon province with estimated hydrocarbon reserves of about 36.2 billion barrels (EIA 2008). The origin of this hydrocarbon is a controversial subject as some published researches believed that the hydrocarbons are sourced from the Akata Formation, while others alleged Agbada Formation (Weber and Daukoru 1975; Short and Stauble 1967). Weber and Daukoru (1975) and Ekweozor and Daukoru (1984) believed that the source of hydrocarbon was only from the Akata Shales, while Short and Stauble (1967) assumed that the shale intercalations within the sands of the Agbada Formation are the main contributor to the hydrocarbon deposit in the basin.

The organic geochemistry of the sediments of the Niger Delta petroleum province has been fairly studied (Ekweozor and Okoye 1980; Nwachukwu and Chukwura 1986; Akaegbobi 2000; Akinlua and Torto 2010; Akinsanpe and Benjamin 2018). Akinlua et al. (2006) studied some shale 


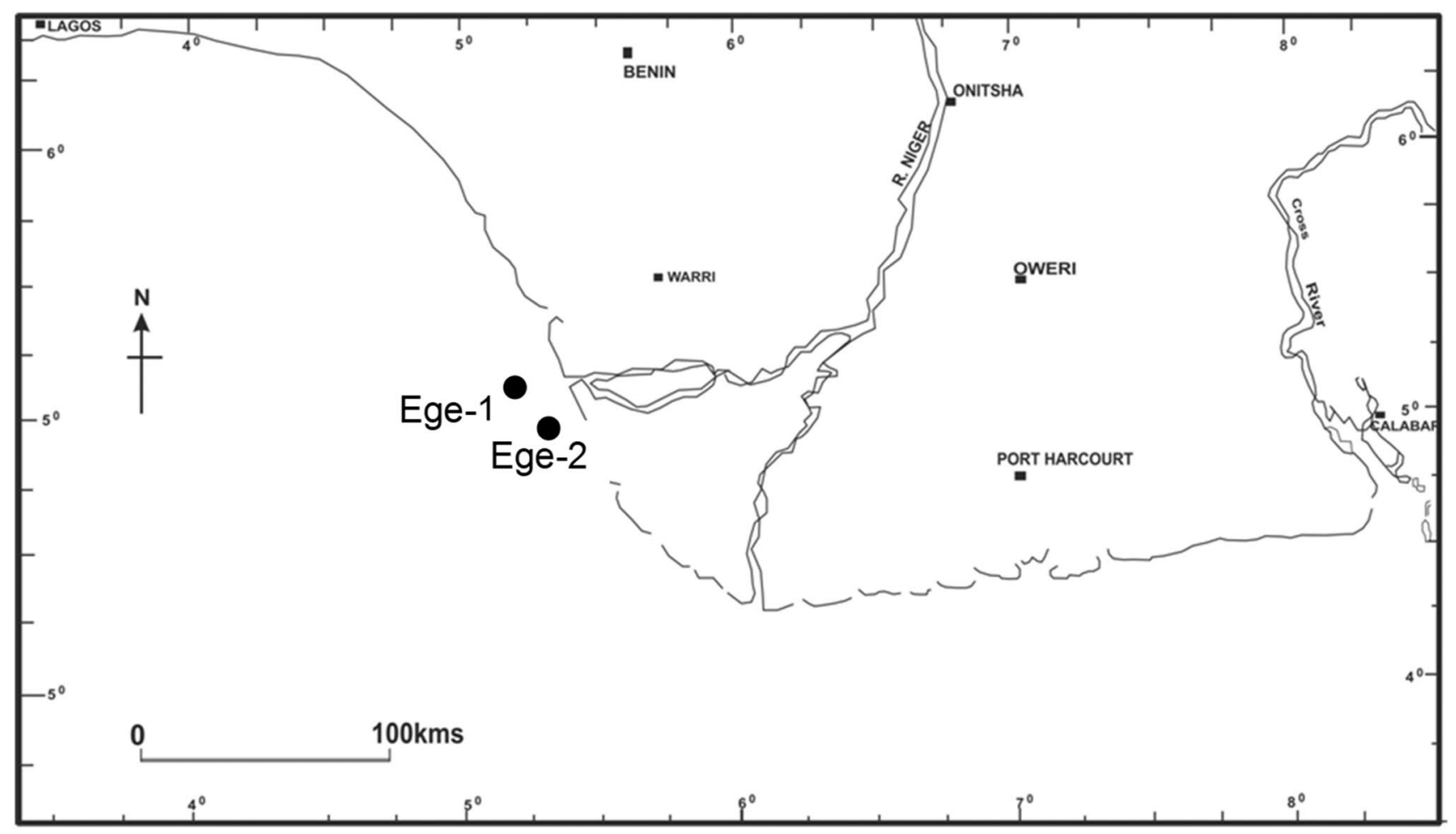

Fig. 1 Location of the Niger Delta and the position of Ege-1 and Ege-2 wells

samples from the Paleogene-Neogene Agbada Formation and analyzed the samples for TOC and Rock-Eval pyrolysis parameters in order to evaluate the effect of oil-based mud contamination on source rock characterization. The results indicated that the raw (unextracted) samples were dominated by Type III kerogen. Conversely, after extraction, both Types II/III and III kerogen were determined. These results established that it is essential that shale samples should be extracted prior to TOC and Rock-Eval pyrolysis for accurate source rock evaluation. Also, Nyantakyi et al. (2014) through their research investigated the hydrocarbon potential of source rocks from Agbada Formation from western Niger Delta. The results of the studied core samples revealed that they have generally good total organic carbon (TOC values ranging between 1.0 and $2.0 \%$ ) contents, suggesting that there exist conditions in the southern section of the studied area that favor organic matter production and preservation. The Rock-Eval results indicated that $50 \%$ of the studied samples from the southern area consist of Type II kerogen, which are capable of generating both oil and gas at suitable temperature in depth. The remaining half of the samples has Type III kerogens which are capable of generating gas. In their conclusion, the Agbada Formation can be regarded as having good petroleum source rocks and could be part of a petroleum system if sufficient burial and maturation have occurred.
Geochemical information (TOC and Rock-Eval pyrolysis data) on the shales from the Agbada Formation of the basin, however, remains scanty, hence this study. Attempt is made by this study to determine the hydrocarbon potential of the shales from the Agbada section of the Niger Delta Basin using organic matter and Rock-Eval pyrolysis data. This will further shed more light on the origin, environment of deposition and thermal maturity of this section of Niger Delta sequence and also increase the existing organic geochemistry knowledge in the basin.

\section{Geological background}

The Tertiary Niger Delta is made of regressive clastic sequences which are stratigraphically divided into three main lithostratigraphic units (Short and Stäuble 1967) (Fig. 2). These units consist of the Akata, Agbada and Benin Formations in ascending order with estimated thickness of about $8535 \mathrm{~m}$ at the central part of the basin. The Paleocene Akata Formation is characterized by uniform pro-deltaic, medium to dark gray, fairly hard shale. The shale is undercompacted with thickness greater than $3680 \mathrm{~m}$. The Akata Formation has rich foraminiferal fauna, with planktonic foraminifera constituting more than $50 \%$ of the microfauna assemblage. 
Fig. 2 Stratigraphic column showing the three formations of the Niger Delta (after Corredor et al. 2005)

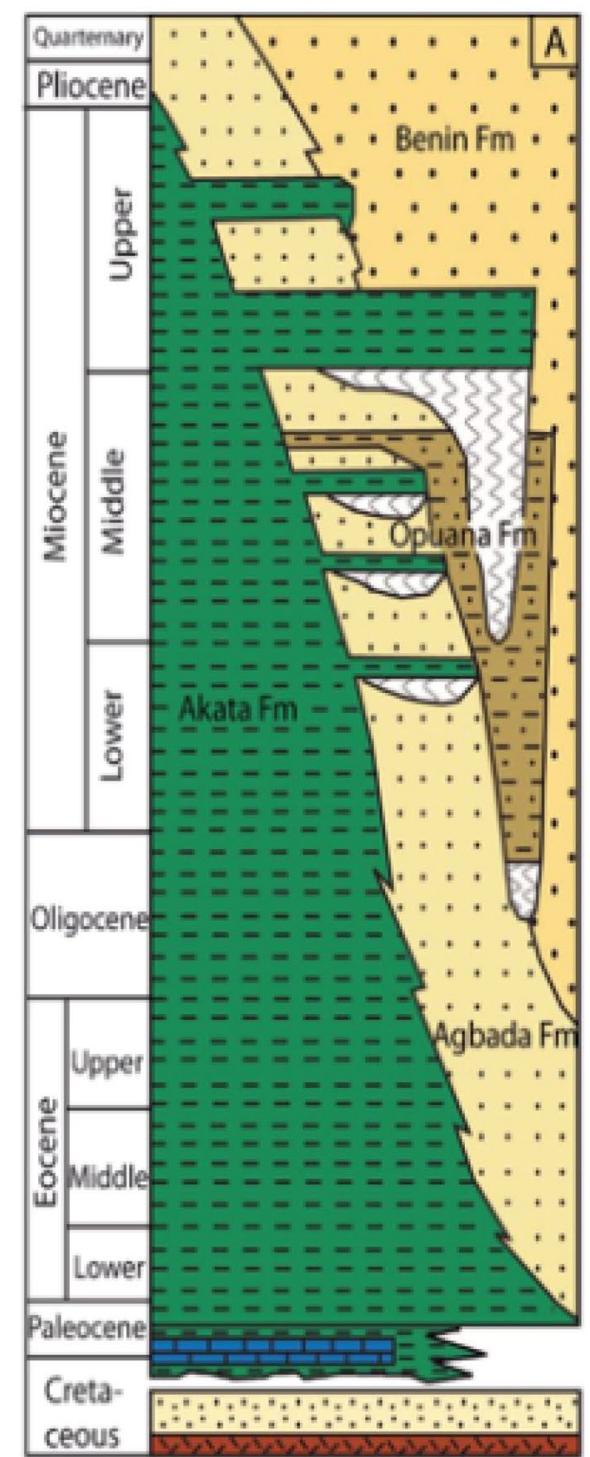

\section{$\therefore$ Continental channel sands}

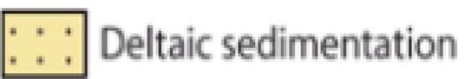

Channel deposits
Marine shale

Carbonates
Basement

Erosion
The Eocene Agbada Formation sits directly above the Akata Formation. The formation consists of alternating cyclic sequence of marine shales and fluvial sandstone deposits (Weber 1971). The sandstones are fairly clean, fine to medium grained, glauconitic and shelly, while the shales are medium to dark gray and fairly consolidated. The thickness of the Agbada Formation at the central part of the basin is $3940 \mathrm{~m}$ and overlain by the Benin Formation of Oligocene age. The Benin Formation, a continental latest Eocene to Recent deposit, is predominantly made up of medium to coarse-grained, highly porous, freshwater-bearing sandstones. The maximum thickness recorded for this formation is $1970 \mathrm{~m}$ (Doust and Omatsola 1990).

\section{Materials and methods}

Fourteen selected ditch cutting shale samples from the Agbada section of Ege-1 and Ege-2 wells offshore Niger Delta, Nigeria, were used in this study (Fig. 1) due to the 
physical observation of their organic matter content. Seven samples each for Ege-1 and Ege-2 wells were selected between depths $1970 \mathrm{~m}$ and $3720 \mathrm{~m}$ and $1950 \mathrm{~m}$ and $3650 \mathrm{~m}$, respectively. These samples are believed to be representative of the whole rock since they are from the same Agbada Formation. The selected samples were then air-dried and crushed in a mortar and pestle treated with $70: 30 \mathrm{v} / \mathrm{v}$ of dichloromethane/methanol and distilled water. This treatment was carried out to remove any form of contamination. The crushed samples were then stored in well-labeled sample bags for further total organic carbon (TOC) and source rock evaluation (Rock-Eval) pyrolysis experimentations.

The sedimentary source rocks represented by weighted percentage of TOC values contain organic matter capable of generating hydrocarbon. According to Tissot and Welte (1984), the lowest value to admit a sedimentary unit as a source rock is $0.3 \%$ for carbonates and $0.5 \%$ for clastics. The TOC values and organic matter types were determined by using Rock-Eval II pyrolysis system. The organic matter types were used to assess the shales hydrocarbon potential (Espitalié et al. 1977). The Rock-Eval experimentation was used for appraising the hydrocarbon potential of shale rocks by introducing $100 \mathrm{mg}$ of the crushed samples in a metal crucible which was placed into the Rock-Eval analyzer. The samples were heated in the furnace for $3 \mathrm{~min}$ at $300{ }^{\circ} \mathrm{C}$. During this process, free hydrocarbon was released from the sample and measured with the flame ionization detector (FID) and then recorded as $\mathrm{S}_{1}$ peak (mg HC/grock). Further increase in pyrolysis temperature to $600{ }^{\circ} \mathrm{C}$ at $25^{\circ} \mathrm{C} / \mathrm{min}$ and hydrocarbon generated during this period was measured on the FID as $\mathrm{S}_{2}$ peak, and the temperature at which the highest hydrocarbon generation occurs during this process was noted as the $T_{\max }\left({ }^{\circ} \mathrm{C}\right)$. The hydrocarbon generated over the temperature range of $300-390{ }^{\circ} \mathrm{C}$ was split into two portions: one part was passed through a thermal conductivity detector (TCD) to measure $\mathrm{CO}_{2}$ as the $\mathrm{S}_{3}$ peak. The $\mathrm{S}_{3}$ peak then provides a measure of the oxygen content of the organic matter. The parameters listed below were achieved at the end of the pyrolysis process:

$\mathrm{S}_{1}$ - the amount of free hydrocarbons exposed before pyrolysis at $300{ }^{\circ} \mathrm{C}$ (mgHC/grock);

$\mathrm{S}_{2}$ - the amount of hydrocarbons exposed by the thermal cracking during programmed temperature increments above $300{ }^{\circ} \mathrm{C}$ in pyrolysis (mgHC/grock);

$\mathrm{S}_{3}$-the amount of $\mathrm{CO}_{2}$ exposed below $300{ }^{\circ} \mathrm{C}\left(\mathrm{mgCO}_{2} /\right.$ grock);

$T_{\max }$ - the temperature at which the $\mathrm{S}_{2}$ peak is at its maximum $\left({ }^{\circ} \mathrm{C}\right)$;

Hydrogen index $(\mathrm{HI})-\left(\mathrm{S}_{2} / \mathrm{TOC}\right) \times 100(\mathrm{mgHC} / \mathrm{gTOC})$; Oxygen index $(\mathrm{OI})-\left(\mathrm{S}_{3} / \mathrm{TOC}\right) \times 100\left(\mathrm{mgCO}_{2} / \mathrm{gTOC}\right)$; Potential yield or generation potential $(\mathrm{PY})-\mathrm{S}_{1}+\mathrm{S}_{2}$ : (mgHC/grock);
Production index $(\mathrm{PI})-\left(\mathrm{S}_{1} / \mathrm{PY}\right)$ producible hydrocarbons in a source rock;

$\mathrm{S}_{2} / \mathrm{S}_{3}$ - oil and gas generation potential or hydrocarbon type index.

\section{Results and discussion}

\section{Organic matter potential and hydrocarbon yield}

The results of the organic carbon richness and Rock-Eval pyrolysis in the wells are presented in Table 1 . The TOC values in corroboration with the Rock-Eval pyrolysis data were used to evaluate the potential of the shale source rocks. The TOC values of all the samples in both wells vary between 1.27 and $3.28 \mathrm{wt} \%$ (with an average of $2.28 \mathrm{wt} \%$, Table 1). These TOC values (0.4-4.4 wt \%) are comparable to the Niger Delta source rocks examined by earlier authors (Ekweozor and Okoye 1980; Nwachukwu et al. 2000; Adekoya et al. 2014), and they are capable of generating hydrocarbon. Nwachukwuet al. (2000) suggested that the Niger Delta shales contained an average of $1.2 \mathrm{wt} \%$ TOC; with weight percent of the studied samples at $2.28 \mathrm{wt} \%$. Tissot and Welte (1984) reported that clastic source rocks of TOC values greater than $0.5 \mathrm{wt} \%$ are capable of generating petroleum. The TOC of Ege- 2 well gradually increases with depth (average value of 2.27) as shale source rocks with at least minimum organic matter content are sufficient to generate petroleum provided there were enough heat and depth of burial more than $2 \mathrm{~km}$ (Akinsanpe and Benjamin 2018). The depth plots of TOC in both wells (Fig. 3) showed that the organic richness of the shales ranges from low to good.

The Rock-Eval pyrolysis analyses revealed that the samples in the two wells displayed a remarkable difference in free hydrocarbon with $S_{1}$ varying from $<1.0$ in most of the samples to over $8.0 \mathrm{mgHC} / \mathrm{g}$ Rock (Table 1). The hydrocarbon $\left(S_{2}\right)$ yield generated during pyrolysis was less than $4.0 \mathrm{mgHC} / \mathrm{gTOC}$ in all the samples except $A 3, B 5$ and $B 7$ shales with $S_{2}$ values $4.80,7.72$ and $9.71 \mathrm{mgHC} / \mathrm{gTOC}$, respectively. This yield is indicative of source rocks with poor generative potential (Bordenave 1993). This is in agreement with the depth plots of $\mathrm{S}_{2}$ which showed that the hydrocarbon potential of the shales in both wells varies from poor to good (Fig. 3) since the $S_{2}$ varies between 1.67 and $9.71 \mathrm{mgHC} /$ grock. Recent hydrocarbon exploration researches showed that $S_{1} / T O C>1$ is suggestive of the presence of considerable free oils in sample (Li et al. 2018; Adekola and Akinlua 2012) and is considered as oil show (Behar et al. 2003). The ratios of $S_{1} /$ TOC range between 0.30-3.74 in Ege-1 well and 0.19-1.77 in Ege-2 well. The values are typical of source rocks entering the oil window except shale samples $A 3, A 4, A 6$ and $B 5(3.74,3.78,2.20$ and 1.77) with values exceeding 1.5 . This is indicative of a contribution of 
Table 1 Results of Rock-Eval pyrolysis of ditch cutting samples from Ege-1 and Ege-2 wells

\begin{tabular}{|c|c|c|c|c|c|c|c|c|c|c|c|c|c|}
\hline Well & $\begin{array}{l}\text { Sample labo- } \\
\text { ratory code }\end{array}$ & Depth (m) & TOC & $S_{1}$ & $S_{2}$ & $\mathrm{~S}_{3}$ & $S_{2} / S_{3}$ & $\mathrm{HI}$ & OI & PI & $T_{\max }\left({ }^{\circ} \mathrm{C}\right)$ & $S_{1} / \mathrm{TOC}$ & PY \\
\hline \multirow[t]{7}{*}{ Ege-1 } & A1 & 1970 & 2.51 & 0.76 & 2.20 & 2.36 & 0.93 & 88 & 94 & 0.26 & 433 & 0.30 & 3.27 \\
\hline & A2 & 2180 & 2.22 & 0.88 & 2.90 & 1.55 & 1.87 & 131 & 70 & 0.23 & 432 & 0.40 & 3.10 \\
\hline & A3 & 2350 & 2.40 & 8.97 & 4.80 & 1.27 & 3.78 & 200 & 53 & 0.65 & 432 & 3.74 & 11.37 \\
\hline & A4 & 2500 & 1.64 & 5.55 & 2.85 & 1.28 & 2.23 & 174 & 78 & 0.66 & 433 & 3.38 & 7.19 \\
\hline & A5 & 2570 & 2.23 & 0.67 & 3.11 & 1.82 & 1.71 & 139 & 82 & 0.18 & 434 & 0.30 & 2.90 \\
\hline & A6 & 3350 & 2.77 & 6.10 & 3.54 & 1.24 & 2.85 & 128 & 45 & 0.63 & 432 & 2.20 & 8.87 \\
\hline & A7 & 3720 & 2.25 & 0.83 & 2.32 & 1.68 & 1.38 & 103 & 75 & 0.26 & 439 & 0.37 & 3.08 \\
\hline \multirow[t]{7}{*}{ Ege-2 } & B1 & 1950 & 1.42 & 0.45 & 1.87 & 1.21 & 1.55 & 132 & 85 & 0.19 & 433 & 0.32 & 1.87 \\
\hline & B2 & 2850 & 1.98 & 0.67 & 2.67 & 1.32 & 2.02 & 135 & 67 & 0.20 & 431 & 0.34 & 2.65 \\
\hline & B3 & 3130 & 2.18 & 0.41 & 1.97 & 3.26 & 0.60 & 90 & 150 & 0.17 & 434 & 0.19 & 2.59 \\
\hline & B4 & 3160 & 2.47 & 1.65 & 2.44 & 1.89 & 1.29 & 99 & 77 & 0.40 & 432 & 0.67 & 4.12 \\
\hline & B5 & 3550 & 3.28 & 5.79 & 7.72 & 1.21 & 6.38 & 235 & 37 & 0.43 & 397 & 1.77 & 9.07 \\
\hline & B6 & 3510 & 1.27 & 0.34 & 1.67 & 2.03 & 0.82 & 131 & 160 & 0.17 & 430 & 0.27 & 1.61 \\
\hline & B7 & 3650 & 3.27 & 3.62 & 9.71 & 1.18 & 8.23 & 297 & 36 & 0.27 & 396 & 1.11 & 6.89 \\
\hline
\end{tabular}

TOC total organic carbon (wt\%), $S_{1}$ mgHC/grock, $S_{2}$ hydrocarbon generated from the thermal breakdown of kerogen (mgHC/grock), $S_{3} \mathrm{CO}_{2}$ value ( $\left.\mathrm{mgCO}_{2} / \mathrm{gTOC}\right), T_{\max }$ the temperature at which the maximum release of hydrocarbons from the cracking of kerogen during pyrolysis $\left({ }^{\circ} \mathrm{C}\right)$, $H I$ Hydrogen index (mgHC/gTOC), OI oxygen index $\left(\mathrm{mgCO}_{2} / \mathrm{gTOC}\right), P I$ production index $(\mathrm{mgHC} / \mathrm{gTOC}), P Y(S 1+S 2)$ potential yield $(\mathrm{mg} \mathrm{HC} /$ grock) and $S_{2} / S_{3}$ hydrocarbon-type index
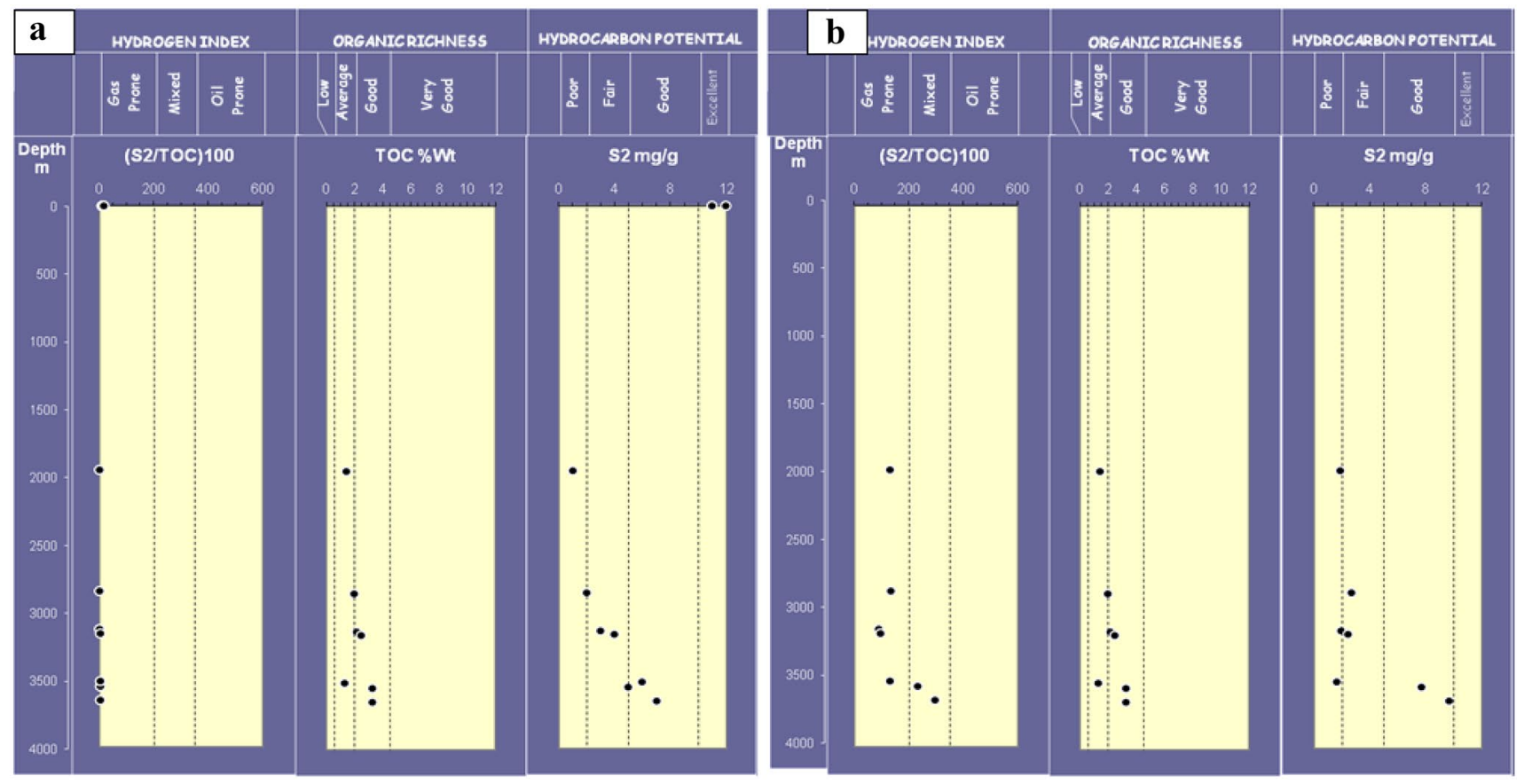

Fig. 3 Depth plots of $S 2 / T O C$, TOC and $S 2$ of a Ege-1 well and b Ege-2 well

nonindigenous oil (Smith 1994). These studied samples (A3, $A 4$ and $A 6$ in Ege-1 well and $B 5, B 7$ in Ege-2 well) of greater depth have $S_{1} /$ TOC $>1$ and are considered as oil show. This is further corroborated with the depth plots of $S_{2} /$ TOC indicating that samples of Ege-1 well are capable of generating gas as those of Ege-2 mainly produce gas/oil (Fig. 3). Peters
(1986) reported that for mature source rock, HI for gas-prone organic matter is less than 150 and that for gas-oil-prone organic matter ranges between 150 and 300, whereas the oilprone organic matter is more than $300 \mathrm{HI}$. The result from this study showed that five samples each from Ege-1 well $(A 1, A 2, A 5, A 6$ and $A 7)$ and Ege-2 well $(B 1, B 2, B 3, B 4$ and 
$B 6)$ have HI values less than $150 \mathrm{mgHC} / \mathrm{gTOC}$. This shows that the organic matter is gas prone. The two other samples in the wells ( $A 3$ and $A 4)$ and (B5 and $B 7$ ) have $\mathrm{HI}$ ranging between 150 and $300 \mathrm{mgHC} / \mathrm{gTOC}$, which signifies gasoil-prone organic matter. These results are comparable to the shale samples analyzed from the Agbada Formation by Nyantakyi et al. (2014). Their result showed that most of the samples studied have HI values less than $150 \mathrm{mgHC} / \mathrm{gTOC}$.

\section{Thermal maturity of the organic matter and hydrocarbon yield}

The samples studied are associated with low $T_{\text {max }}\left(<432^{\circ} \mathrm{C}\right.$ in Ege-1 well and $<400{ }^{\circ} \mathrm{C}$ in Ege-2 well) showing decreasing trend with $T_{\max }$. This is suggestive of an early onset of hydrocarbon generation or an abnormal trend due to influence from in-migrated hydrocarbons ( $\mathrm{Li}$ et al. 2018). This possibility is corroborated with the plot of $\mathrm{HI}$ against
$T_{\max }$ and HI against TOC, and the ratios of $S_{2} / S_{3}>1 \mathrm{sug}$ gest the samples studied as immature to mature Types II to III organic matter capable of generating fair oil to gas/ oil (Figs. 4, 5). This plot agreed with the plot of $S_{2}$ against TOC signifying that the samples are mainly Type II-Type III organic matter (Fig. 4).

The total hydrocarbon yield (PY) determined by the sum of $S_{1}$ and $S_{2}$ for the wells showed that PY ranges from 2.96 to $13.77 \mathrm{mgHC} /$ grock in Ege-1 well (average of $6.50 \mathrm{mgHC} /$ grock) indicative of fairly significant amount of hydrocarbon generation in the samples. The highest hydrocarbon yield of $13.77 \mathrm{mgHC} / \mathrm{grock}$ was recorded within Ege-1 well section at $2350 \mathrm{~m}$ which indicates rich source rock with a TOC value of $2.40 \mathrm{wt} \%$ has potential to expel generated hydrocarbon. Ege-2 well section also showed a low $\mathrm{PY}(<5.85 \mathrm{mgHC} /$ grock $)$ indicating that the shales within this well generated fairly significant hydrocarbon which is low for expulsion. Rich source rock with potentials to expel
Fig. 4 Distribution of the shale samples within the Agbada Formation in a Ege- 1 and $\mathbf{b}$ Ege-2 wells on the hydrogen index against weight percent of total organic carbon diagram
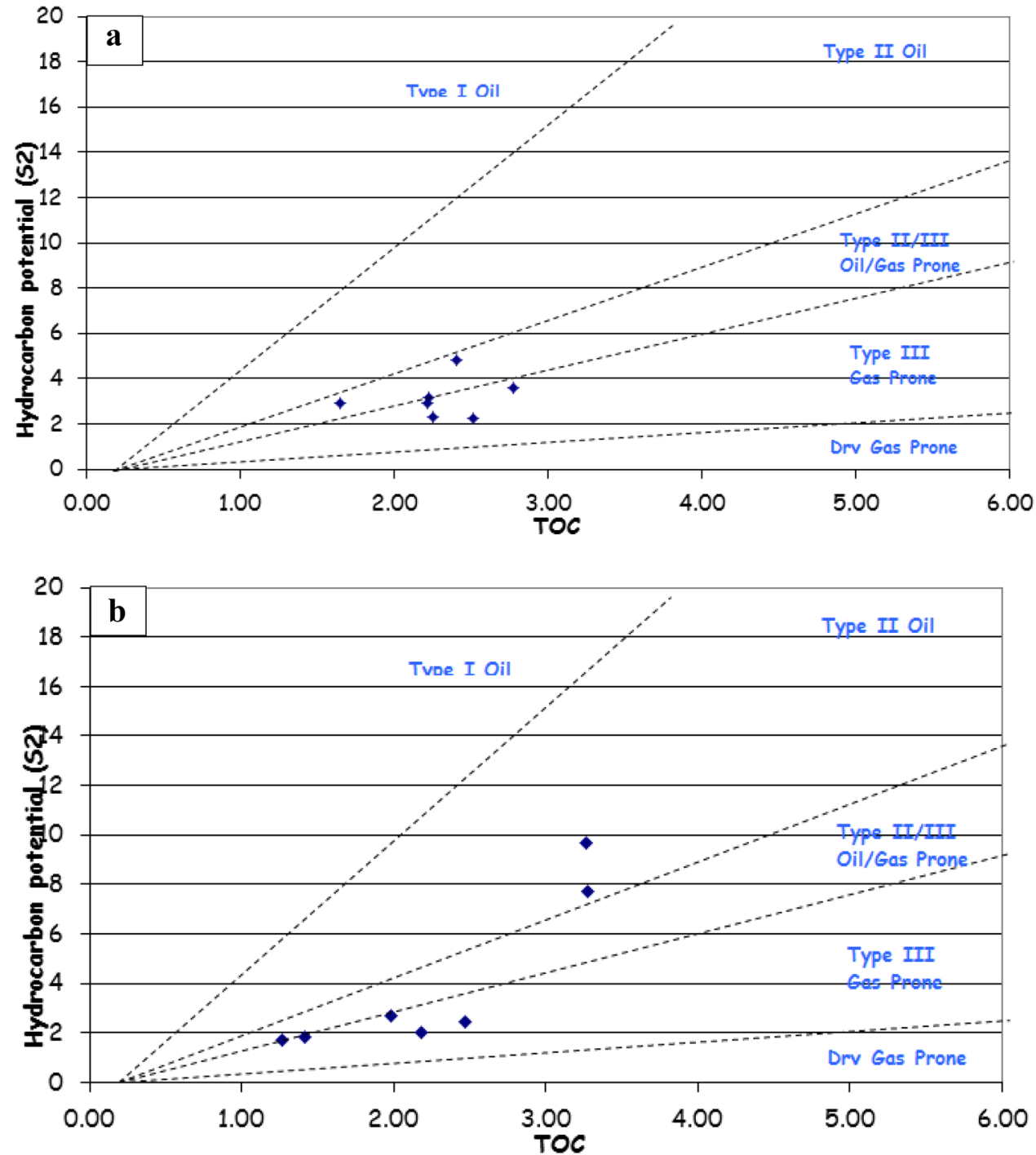

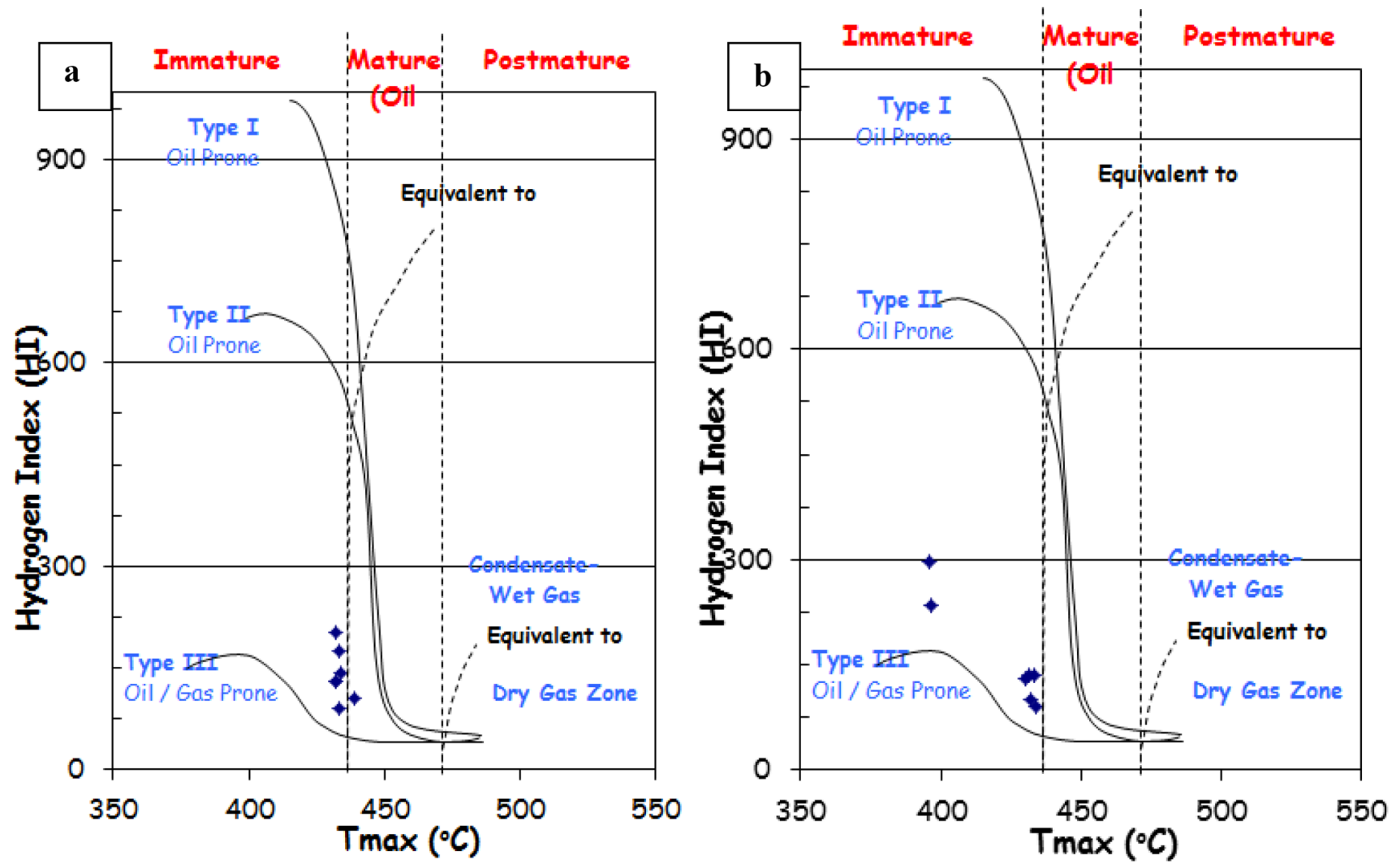

Fig. 5 Distribution of the shale samples within the Agbada Formation in the a Ege-1 well and $\mathbf{b}$ Ege-2 well on the hydrogen index against $T_{\max }$ $\left({ }^{\circ} \mathrm{C}\right)$ plots

generated hydrocarbon occurred at $3550 \mathrm{~m}$ and $3650 \mathrm{~m}$ (PY > 13 mgHC/grock).

\section{Conclusion}

The TOC and Rock-Eval pyrolysis results from the shale samples of the Agbada Formation in wells Ege-1 and Ege-2 were used to deduce the hydrocarbon potential of selected shale samples from the wells. The results showed that all the shale samples in both wells have high TOC values ranging between 1.27 and 3.28 and Types II and III kerogens capable of generating oil to gas/oil. The plot of the HI against $T_{\max }$ which is indicative of thermal maturity with $S 1, S_{2}, S_{3}$ and OI parameters showed that the samples range from immature to mature Types II-III organic matter capable of generating fair oil to gas/oil.

Acknowledgements The authors are grateful to GHGeochem Limited, $\mathrm{UK}$, for the use of their laboratory facility for this study.

Authors' contributions FSL contributed to conception of the idea of the research, sample analysis, final reporting. ASA contributed to interpretation. OMB contributed to drafting of manuscript. AOT contributed to interpretation and proofreading of manuscript.
Funding Funding was done by authors for the purpose of research without any external input.

\section{Compliance with ethical standards}

Conflict of interest The authors declare that they do not have conflict of interest.

Availability of data and material The data from the work are included in the write-up.

Open Access This article is licensed under a Creative Commons Attribution 4.0 International License, which permits use, sharing, adaptation, distribution and reproduction in any medium or format, as long as you give appropriate credit to the original author(s) and the source, provide a link to the Creative Commons licence, and indicate if changes were made. The images or other third party material in this article are included in the article's Creative Commons licence, unless indicated otherwise in a credit line to the material. If material is not included in the article's Creative Commons licence and your intended use is not permitted by statutory regulation or exceeds the permitted use, you will need to obtain permission directly from the copyright holder. To view a copy of this licence, visit http://creativecommons.org/licenses/by/4.0/. 


\section{References}

Adekola SA, Akinlua A (2012) Source rock characterization within the stratigraphic settings of the orange basin South Africa. Pet Sci Technol 30(6):545-558

Adekoya JA, Ola PS, Olabode SO (2014) Possible bornu basin hydrocarbon habitat - A review. Int J Geosci 5:983-996

Akaegbobi IM (2000) Application of geochemical techniques in kerogen classification and source rock evaluation of the Agbada shale Eastern Niger Delta. J Min Geol 36:175-189

Akinlua A, Ajayi TR, Jarvie DM, Adeleke BB (2006) A re-appaisal of the application of Rock-Eval pyrolysis to source rock studies in the Niger Delta. J Pet Geol 28(1):39-48

Akinlua A, Torto N (2010) Geochemical evaluation of Niger Delta sedimentary organic rocks: a new insight. Int J Earth Sci 100:1401-1411

Akinsanpe OT, Benjamin UK (2018) Down-hole geochemistry of the core sediments from part of the Niger Delta Basin, southern Nigeria. FUTA J Res Sci 14(1):1-11

Behar F, Lewan M, Lorant F, Vandenbroucke M (2003) Comparison of artificial maturation of lignite in hydrous and nonhydrous conditions. Org Geochem 34(4):575-600

Bordenave ML (1993) Applied petroleum geochemistry. Editions Technip, Paris, p 524

Corredor F, Shaw JH, Bilotti F (2005) Structural styles in the deepwater fold and thrust belts of the Niger Delta. AAPG Bulletin 89:753-780

Cullers RL, Basu A, Suttner L (1988) Geochemical signature of provenance in sand-size material in soils and stream sediments near the Tobacco Root batholith, Montana, USA. Chem Geol 70(4):335-348

Doust H, Omatsola EM (1990) Niger Delta. In: Edwards JD, Santogrossi PA (eds) Divergent/passive Margins Basins. American Association of Petroleum Geologist Memoir, Tulsa, pp 239-248

Ekweozor CM, Okoye NV (1980) Petroleum source-bed evaluation of Tertiary Niger Delta. Am Assoc Pet Geol Bull 64:1251-1259

Ekweozor CM, Daukoru EM (1984) Petroleum source-bed evaluation of Tertiary Niger Delta: reply. Am Assoc Pet Geol Bull 68:390-392

Energy Information Administration (EIA) 2008. https://www.eia.doe. gov/emeu/cabs/Nigeria/Oil.html

Espitalie J, Madec M, Tissot B, Mennig J, Leplat P (1977) Source rock characterization method for petroleum exploration. In: Offshore Technology Conference, Doi: https://doi.org/10.4043/2935-MS

Frimmel HE (2009) Trace element distribution in Neoproterozoic carbonates as palaeoenvironmental indicator. Chem Geol 258:338-353
Li M, Chen Z, Cao T, Ma X, Liu X, Li Z, Jiang Q, Wu S (2018) Expelled oils and their impacts on Rock-Eval data interpretation, Eocene Qianjiang formation in Jianghan Basin, China. Int J Coal Geol 191:37-48

Madhavaraju J, Lee YI (2009) Geochemistry of the Dalmiapuram formation of the Uttatur Group (Early Cretaceous), Cauvery basin, southeastern India: implications on provenance and paleo-redox conditions. Revista Mexicana de Ciencias Geológicas 26:380-394

Nagarajan R, Madhavaraju J, Nagendra R, Armstron-Altrin JS, Moutte J (2007) Geochemistry of Neoproterozoic shales of the Rabanpalli Formation, Bhima Basin, Northern Karnataka, southern India: implications for provenance and paleoredox conditions. Revista Mexicana de Ciencias Geologicas 24:150-160

Nwachukwu JI, Chukwura PI (1986) Organic matter of the Agbada formation in Niger Delta Nigeria. Am Asso Petrol Geol Bull 70:48-55

Nwachukwu JI, Obiajunwa EI, Obioh IB (2000) Elemental analysis of Kerogens from the Niger Delta, Nigeria. Proceedings of 5th International Conference and Exhibition, 139-145

Nyantakyi EK, Hu WU, Borkloe JK, Nagre RD, Frimpong IK (2014) Geochemical Investigation of Potential Source Rocks for Agbada Formation, Osioka South Area, Western Niger Delta. Niger Geosci 4(1):13-22

Peters KE (1986) Guidelines for evaluating petroleum source rocks using programmed pyrolysis. Am Asso Petrol Geol Bull 70(3):318-329

Philp RP (2014) Formation and geochemistry of oil and gas. Treatise Geochem 7:223-256

Short KC, Stauble AJ (1967) Outline of the geology of the Niger Delta. Am Asso Petrol Geol Bull 51:761-779

Smith JT (1994) Petroleum system logic as an exploration tool in frontier setting. In: Magoon LP, Dow WG (eds) The petroleum system from source to trap. AAPG Memoir, Tulsa, pp 25-49

Tissot BP, Welte DH (1984) Petroleum formation and occurrence. Springer, Berlin, p 538

Weber KJ, Daukoru EM (1975) Petroleum geology aspects of the Niger Delta. Proc World Pet Congress 2:209-222

Weber KJ (1971) Sedimetological aspects of oil fields in the Niger Delta. Geologieen Mynbouw 50(59-576):1971

Publisher's Note Springer Nature remains neutral with regard to jurisdictional claims in published maps and institutional affiliations. 